\title{
Studi Numerik Model Virus Hepatitis B dengan Pengaruh Penyembuhan dan Absorpsi
}

\author{
Lisa Risfana Sari ${ }^{1 *}$, Puji Andayani ${ }^{2}$ \\ *e-mail: lisa.sari@uisi.ac.id \\ ${ }^{1,2}$ Universitas Internasional Semen Indonesia, Gresik
}

\begin{abstract}
The phenomenon of Hepatitis B outbreak almost occurs in all developing countries including Indonesia. Hepatitis B infection can develop into acute or chronic. In the chronic stage, the infection can cause liver complications such as liver cirrhosis or liver cancer or even death. Mathematical modeling have been widely used to study the Hepatitis B virus infection. In this study a mathematical model is constructed by considering non-cytolytic immune response and pathogen absorption. The model is analyzed by determining the equilibrium point of the model, determining the existence of the equilibrium point, and analyzing the stability of the equilibrium point of the model with numerical simulation. In this case, numerical analysis is used to illustrate the conditions of infection-free and infected. Furthermore, the relation of the stability requirements of each equilibrium point is studied. The results show that there are two equilibrium points, uninfected and infected equilibrium point. Both of the uninfected equilibrium point and infected equilibrium point is asymptotically stable if a certain condition are met. Based on these results, the causes of a persistent infection are studied.
\end{abstract}

Keywords: absorption, cure, Hepatitis B, model, numerical.

\begin{abstract}
ABSTRAK
Fenomena wabah Hepatitis B hampir terjadi di seluruh negara berkembang termasuk Indonesia. Infeksi Hepatitis B dapat berkembang menjadi akut atau kronik. Pada tahap kronik, infeksi tersebut dapat mengakibatkan komplikasi hati seperti sirosis hati maupun kanker hati atau bahkan kematian. Studi infeksi virus Hepatitis B menggunakan model matematika telah banyak dikembangkan. Pada penelitian ini dikonstruksi model matematika dengan mempertimbangkan respon imun non-sitolitik dan absorpsi patogen. Model dianalisis dengan menentukan titik kesetimbangan model, menentukan eksistensi titik kesetimbangan, dan menganalisis kestabilan titik kesetimbangan model melalui simulasi numerik. Dalam hal ini, analisis numerik digunakan untuk mengilustrasikan kondisi bebas infeksi dan terinfeksi. Selanjutnya, dipelajari kaitan syarat kestabilan antara kedua titik kesetimbangan. Hasil analisis menunjukkan bahwa terdapat dua titik kesetimbangan pada model, yaitu titik kesetimbangan bebas infeksi dan terinfeksi. Titik kesetimbagan bebas infeksi maupun titik kesetimbangan terinfeksi stabil asimtotik jika syarat tertentu terpenuhi. Berdasarkan hasil tersebut, dipelajari penyebab terjadinya infeksi persisten.
\end{abstract}

Kata Kunci: absorpsi, Hepatitis B, model, numerik, penyembuhan.

\section{PENDAHULUAN}

Infeksi virus Hepatitis B (HBV) merupakan masalah kesehatan global.
Diperkirakan terdapat 248 juta orang di seluruh dunia yang merupakan carier 
HBV, dengan sekitar 600.000 diantaranya meninggal setiap tahun akibat penyakit hati terkait (Teo and Lok, 2018). Infeksi HBV dapat mengakibatkan infeksi akut hingga kronis. Sebagian besar infeksi akut HBV pada orang dewasa dapat disembuhkan secara total, sedangkan $\quad 1 \%-2 \%$ diantaranya berkembang menjadi infeksi akut fulminant, yang mengakibatkan inflamasi dan kerusakan jaringan hati secara masif ("Pinkbook | Hepatitis B | Epidemiology of Vaccine Preventable Diseases | CDC," 2018). Mengingat bahaya yang diakibatkan infeksi HBV, upaya pencegahan dan pengendalian infeksi HBV sangat diperlukan.

Telah banyak berkembang studi yang mempelajari HBV di dunia, termasuk diantaranya dengan menggunakan pemodelan matematika. Kompleksitas interaksi penularan dalam suatu populasi mengakibatkan pemahaman penularan dalam skala besar sangat sulit dilakukan tanpa adanya struktur formal dari model matematika (Hethcote, 1989).

Dinamika infeksi virus tidak terlepas dari bagaimana proses infeksi itu terjadi, tingkat kejadian infeksi maupun respon imun akibat adanya infeksi tersebut. Seperti pada proses infeksi virus umumnya, infeksi Hepatitis B diawali dengan adanya adsorbsi patogen yang dilanjutkan injeksi DNA virus ke dalam sel inang. Hal ini mengakibatkan terjadinya degradasi virus. Fase infeksi pun berlanjut di dalam sel inang hingga terbentuk DNA-VHB (virus Hepatitis B) dalam kapsid. Kapsid DNA-VHB kemudian dapat diselubungi dan disekresikan ke dalam darah sebagai virus bebas atau diangkut kembali ke inti sel (Bartholomeusz et al., 2006). Apabila proses infeksi terjadi secara terus menerus maka infeksi dapat menyebar ke sel hati sehat lainnya.

Infeksi virus hepatitis B bersifat nonsitopatik yaitu tidak memicu adanya respon imun non spesifik, sehingga eliminasi virus sebagian besar diakibatakan oleh adanya respon imun adaptif/spesifik. Salah satu sel imun yang berperan dalam respon imun adaptif adalah $\mathrm{CD}^{+} \mathrm{T}$ sel, dimana sel ini tidak hanya membunuh sel terinfeksi namun juga mensekresi sitokin yang berfungsi untuk menghambat replikasi virus secara non sitolitik, yang dalam hal ini mengakibatkan penyembuhan sel terinfeksi (Guidotti, 1999).

Model virus Hepatitis B yang memperhitungkan respon imun nonsitolitik telah dikembangkan oleh Wang dkk.(Wang et al., 2010) dan Yousfi dkk.(Yousfi et al., 2011). Manna dan Chakrabarty (Manna and Chakrabarty, 2015) mengembangkan model dengan memperhatikan populasi kapsid HBV DNA. Dubey dkk. (Dubey et al., 2016) mengembangkan model dengan mempertimbangkan absorpsi patogen ketika proses infeksi terjadi. Berdasarkan penelitian tersebut, dikembangkan model virus Hepatitis B dengan respon imun non-sitolitik dan absorpsi patogen. Selanjutnya, perilaku solusi model dianalisis dan diilustrasikan dalam simulasi numerik. Berdasarkan hasil tersebut dipelajari faktor penentu terjadinya infeksi persisten yang ditandai dengan tercapainya kestabilan titik kesetimbangan terinfeksi.

\section{BAHAN DAN METODE Konstruksi Model}

Untuk memahami dinamika infeksi virus Hepatitis B dengan adanya pengaruh absorpsi patogen dan penyembuhan sel, dikembangkan model dengan mempertimbangkan empat populasi yang mewakili sel hati rentan sel hati terinfeksi kapsid DNA-VHB intraseluler dan virus bebas. Beberapa asumsi yang digunakan dalam model adalah, adanya transmisi kapsid DNAVHB intraseluler menjadi virus bebas, adanya penyembuhan sel hati terinfeksi 
akibat respon imun non-sitolitik, dan adanya degradasi virus bebas yang terjadi saat virus menginfeksi sel hati sehat.

Andaikan $H_{s}(t)$ merupakan kepadatan populasi sel hati sehat, $H_{i}(t)$ adalah kepadatan populasi sel hati terinfeksi, $D_{n}(\boldsymbol{t})$ adalah kepadatan populasi kapsid DNA-VHB intraseluler, dan $V(t)$ adalah kepadatan populasi virus Hepatitis B bebas, pada waktu $t$ satuan. Diasumsikan sel hati di produksi dengan laju konstan s seperti pada persamaan (1).

$$
\frac{d H_{s}(t)}{d t}=s
$$

Sel hati memiliki rentang hidup tertentu. Adanya kematian alami sel hati dengan laju $\mu$ mengakibatkan laju pertumbuhan kepadatan populasi sel hati sehat menurun.

$$
\frac{d H_{s}(t)}{d t}=-\mu H_{s}(t)
$$

Berdasarkan penelitian Wang dkk. [5] dan Hattaf dkk. [6], laju infeksi virus Hepatitis B dinyatakan dalam fungsi insidensi standar berikut

$$
f\left(H_{s}(t), V(t)\right)=\frac{k H_{s}(t) V(t)}{H_{s}(t)+H_{i}(t)}
$$

dengan $k$ menyatakan tingkat infeksi. Oleh karena adanya infeksi tersebut, maka laju pertumbuhan kepadatan populasi sel hati sehat mengalami penurunan.

$$
\frac{d H_{g}(t)}{d t}=-\frac{k H_{g}(t) V(t)}{H_{g}(t)+H_{i}(t)}
$$

Respon imun nonsitolitik mengakibatkan laju penyembuhan sel hati terinfeksi sebesar $p$. Hal ini mengakibatkan laju pertumbuhan kepadatan populasi sel hati sehat meningkat.

$$
\frac{d H_{g}(t)}{d t}=p H_{i}(t)
$$

Berdasarkan persamaan (1), (2), (3), dan (4), maka diperoleh formulasi pertumbuhan kepadatan populasi sel sehat berikut

$\frac{d H_{g}(t)}{d t}=s-\mu H_{s}(t)-\frac{k H_{g}(t) V(t)}{H_{g}(t)+H_{i}(t)}+p H_{i}(t)$

Sama halnya pada sel hati sehat, sel hati terinfeksi memiliki durasi hidup tertentu atau juga mengalami kematian alami. Diasumsikan laju kematian alami sel hati terinfeksi sebesar $\delta$ mengakibatkan penurunan laju pertumbuhan kepadatan populasi sel hati terinfeksi.

$$
\frac{d H_{i}(t)}{d t}=-\delta H_{i}(t)
$$

Adanya infeksi virus mengakibatkan laju pertumbuhan kepadatan populasi sel hati terinfeksi meningkat seperti pada persamaan (6).

$$
\frac{d H_{i}(t)}{d t}=\frac{k H_{g}(t) V(t)}{H_{g}(t)+H_{i}(t)}
$$

Sementara itu, penyembuhan sel terinfeksi mengakibatkan laju pertumbuhannya menurun.

$$
\frac{d H_{i}(t)}{d t}=-p H_{i}(t)
$$

Berdasarkan persamaan (5), (6), dan (7) maka diperoleh formulasi laju pertumbuhan kepadatan populasi sel hati terinfeksi adalah

$$
\frac{d H_{i}(t)}{d t}=\frac{k H_{g}(t) V(t)}{H_{g}(t)+H_{i}(t)}-(\delta+p) H_{i}(t)
$$

Kapsid DNA-VHB intraseluler diasumsikan diproduksi oleh sel hati terinfeksi dengan laju $\boldsymbol{a}$.

$$
\frac{d D_{n}(t)}{d t}=a H_{i}(t)
$$


Kematian sel hati terinfeksi juga berdampak pada kematian kapsid DNAVHB intraseluler, sehingga laju pertumbuhan kepadatan populasi kapsid DNA-VHB intraseluler berkurang dengan laju yang sama sebesar $\delta$ seperti berikut

$$
\frac{d D_{n}(t)}{d t}=-\delta D_{n}(t)
$$

Diasumsikan laju transmisi kapsid DNAVHB intraseluler menjadi virus bebas sebesar $\beta$ mengakibatkan laju pertumbuhan kepadatan populasi kapsid DNA-VHB intraseluler berkurang.

$$
\frac{d D_{n}(t)}{d t}=-\beta D_{n}(t)
$$

Menggunakan persamaan (8), (9), dan (10) diperoleh formulasi laju pertumbuhan kepadatan populasi kapsid DNA-VHB intraseluler.

$$
\frac{d D_{n}(t)}{d t}=a H_{i}(t)-(\delta+\beta) D_{n}(t)
$$

Virus bebas bertambah akibat adanya transmisi kapsid DNA-VHB intraseluler, sehingga laju pertumbuhan kepadatan populasinya meningkat.

$$
\frac{d V(t)}{d t}=\beta D_{n}(t)
$$

Laju pertumbuhan kepadatan populasi virus bebas menurun akibat kematian alami virus dengan laju sebesar $c$.

$$
\frac{d V(t)}{d t}=-c V(t)
$$

Degradasi virus terjadi akibat adanya absorpsi virus pada saat proses infeksi berlangsung. Hal ini mengakibatkan penurunan laju pertumbuhan kepadatan populasi virus bebas.

$$
\frac{d V(t)}{d t}=-\frac{k H_{g}(t) V(t)}{H_{g}(t)+H_{i}(t)}
$$

Merujuk pada persamaan (11), (12), dan (13) diperoleh formulasi laju pertumbuham kepadatan populasi virus bebas adalah

$$
\frac{d V(t)}{d t}=\beta D_{n}(t)-c V(t)-\frac{k H_{g}(t) V(t)}{H_{g}(t)+H_{i}(t)}
$$

Dengan demikian, formulasi model virus Hepatitis B dengan pengaruh penyembuhan dan absorpsi seperti pada sistem (14).

$$
\begin{aligned}
& \frac{d H_{g}(t)}{d t}=s-\mu H_{s}(t)-\frac{k H_{g}(t) V(t)}{H_{g}(t)+H_{i}(t)}+p H_{i}(t) \\
& \frac{d H_{i}(t)}{d t}=\frac{k H_{g}(t) V(t)}{H_{g}(t)+H_{i}(t)}-(\delta+p) H_{i}(t) \\
& \frac{d D_{n}(t)}{d t}=a H_{i}(t)-(\delta+\beta) D_{n}(t) \\
& \frac{d V(t)}{d t}=\beta D_{n}(t)-c V(t)-\frac{k H_{g}(t) V(t)}{H_{g}(t)+H_{i}(t)}
\end{aligned}
$$

\section{Penentuan Titik Kesetimbangan}

Titik kesetimbangan sistem (14) merupakan solusi sistem dengan laju pertumbuhan masing-masing populasi bernilai nol. Titik kesetimbangan mengilustrasikan solusi konstan sistem.

\section{Penentuan Kestabilan Titik Kesetimbangan}

Kestabilan titik kesetimbangan diamati dari nilai eigen yang diperoleh dari persamaan karakteristik yang diperoleh dari Matriks Jacobi sistem (14). Karakteristik kestabilan titik kesetimbangan meliputi stabil atau tidaknya titik kesetimbangan. Jika titik kesetimbangan stabil, maka setiap solusi sistem dengan kondisi awal berbeda akan konvergen menuju titik kesetimbangan tersebut, dan juga sebaliknya.

\section{Eksperimen Numerik}

Sistem (14) adalah sistem non linear, sehingga solusi analitik sistem tidak mudah ditentukan. Oleh karena itu, simulasi numerik akan dilakukan untuk menyelidiki perilaku sistem. Solusi numerik dari sistem dapat memberikan gambaran kepadatan populasi dalam jangka panjang. Untuk menentukan solusi 
numerik model virus Hepatitis B dengan pengaruh penyembuhan dan absorpsi patogen, digunakan metode Runge Kutta orde 4.

\section{HASIL DAN PEMBAHASAN Titik Kesetimbangan}

Titik kesetimbangan sistem (14) diperoleh dari solusi sistem persamaan berikut

$0=s-\mu H_{s}(t)-\frac{k H_{s}(t) V(t)}{H_{s}(t)+H_{i}(t)}+p H_{i}(t)$

$0=\frac{k H_{g}(t) v(t)}{H_{s}(t)+H_{i}(t)}-(\delta+p) H_{i}(t)$

$0=a H_{i}(t)-(\delta+\beta) D_{n}(t)$

$0=\beta D_{n}(t)-c V(t)-\frac{k H_{g}(t) V(t)}{H_{s}(t)+H_{i}(t)}$

Hasil perhitungan menunjukkan bahwa sistem (14) memiliki dua titik kesetimbangan sebagai berikut

i. Titik bebas infeksi dengan kepunahan sel hati terinfeksi, kapsid DNA-VHB intraseluler dan virus bebas $E_{0}=(s / \mu, 0,0,0)$

ii. Titik terinfeksi

$$
\begin{aligned}
E_{1} & =\left(H_{s}^{*}, H_{i}^{*}, D_{n}^{*}, V^{*}\right) \text { dimana } \\
H_{s}^{*} & =\frac{\triangle_{1} c s}{\triangle_{1} c \boldsymbol{\mu}+\triangle_{2} \delta} \\
H_{i}^{*} & =\frac{\Delta_{2} s}{\Delta_{1} c \boldsymbol{\mu}+\Delta_{2} \delta} \\
D_{n}^{*} & =\frac{\triangle_{2} s \boldsymbol{a}}{(\boldsymbol{\beta}+\delta)\left(\triangle_{1} \boldsymbol{c} \boldsymbol{\mu}+\triangle_{2} \delta\right)} \\
V^{*} & =\frac{\triangle_{2} s\left(\frac{\triangle_{2}}{c+\boldsymbol{k}}+\frac{\boldsymbol{a c} \beta}{\boldsymbol{c}+\boldsymbol{k}}\right)}{c(\beta+\delta)\left(\triangle_{2} \delta+\boldsymbol{c} \boldsymbol{\mu} \triangle_{1}\right)}
\end{aligned}
$$

dengan

$$
\begin{aligned}
& \Delta_{1}=(\delta+p)(\beta+\delta) \text { dan } \\
& \Delta_{2}=a k \beta-(c+k) \Delta_{1} .
\end{aligned}
$$

\section{Kestabilan Titik Kesetimbangan}

Matriks Jacobi sistem (14) pada titik $\left(H_{s}, H_{i}, D_{n}, V\right)$ ditunjukkan berikut.

$$
J=\left[\begin{array}{llll}
J_{1,1} & J_{1,2} & J_{1,3} & J_{1,4} \\
J_{2,1} & J_{2,2} & J_{2,3} & J_{2,4} \\
J_{3,1} & J_{3,2} & J_{3,3} & J_{3,4} \\
J_{4,1} & J_{4,2} & J_{4,3} & J_{4,4}
\end{array}\right]
$$

dengan,

$J_{1, \mathbf{1}}=-\mu-\frac{k V}{H_{s}+H_{i}}+\frac{k H_{s} V}{\left(H_{s}+H_{i}\right)^{2}}$

$J_{1,2}=\frac{k H_{g} V}{\left(H_{g}+H_{i}\right)^{2}}+p$

$J_{1,3}=0$

$J_{1,4}=-\frac{k H_{g}}{H_{s}+H_{i}}$

$J_{2,1}=\frac{k V}{H_{s}+H_{i}}-\frac{k H_{S} V}{\left(H_{s}+H_{i}\right)^{2}}$

$J_{2,2}=-\frac{k H_{g} V}{\left(H_{s}+H_{i}\right)^{2}}-\delta-p$

$J_{2,3}=0$

$J_{2,4}=\frac{k H_{s}}{H_{s}+H_{3}}$

$J_{3,1}=0$

$J_{3,2}=a$

$J_{3,3}=-\beta-\delta$

$J_{3,4}=0$

$J_{4, \mathbf{1}}=-\frac{k V}{H_{s}+H_{i}}+\frac{k H_{g} V}{\left(H_{s}+H_{i}\right)^{2}}$

$J_{4,2}=\frac{k H_{g} V}{\left(H_{S}+H_{i}\right)^{2}}$

$J_{4,3}=\beta$

$J_{4,4}=-c-\frac{k H_{g}}{H_{s}+H_{i}}$

Titik kesetimbangan $\left(H_{s}, H_{i}, D_{n}, V\right)$ dari sistem (14) bersifat stabil asimotik jika bagian real dari semua nilai eigen $J\left(H_{s}, H_{i}, D_{n}, V\right)$ bernilai negatif. Analisis nilai eigen dari matriks Jacobi pada masing-masing titik kesetimbangan dilakukan dengan menggunakan simulasi numerik.

\section{Simulasi Numerik}

Simulasi numerik dilakukan dengan bantuan software Maple. Terdapat tiga nilai awal yang diteliti pada simulasi numerik, yang masing-masing mewakili kondisi dengan tingkat infeksi berbeda. Nilai awal IC1 menunjukkan kondisi awal manusia sehat yang belum terinfeksi virus, nilai awal IC2 dan IC3 menunjukkan kondisi awal manusia terinfeksi, dimana pada IC3 tingkat 
infeksi lebih tinggi atau lebih berat. Tiga nilai awal tersebut dinyatakan berikut

$$
\begin{gathered}
I C 1=(1360,0,0,0.33) \\
I C 2=(800,1.8,0.6,120) \\
I C 3=(300,6,60,200)
\end{gathered}
$$

Nilai parameter yang digunakan pada simulasi pertama yaitu

$$
\begin{gathered}
s=10, \mu=0.01, k=0.0018, \delta=0.0693 \\
, a=150, \beta=0.87, c=5, p=0.1
\end{gathered}
$$

Berdasarkan nilai-nilai parameter tersebut, titik kesetimbangan $E_{0}$ eksis sedangkan titik kesetimbangan $E_{1}$ tidak eksis. Nilai $E_{0}$ adalah $E_{0}=(1000,0,0,0)$. Nilai eigen dari matriks Jacobi pada $E_{0}$ adalah $(-0.01,-0.33,-1.3,-4.99)$. Sebagai konsekuensi dari syarat kestabilan maka titik $E_{0}$ bersifat stabil asimtotik. Hasil ini ditunjukkan pada Gambar 1.

Nilai awal pada Gambar 1 menunjukkan kepadatan populasi awal dari sel hati sehat (tidak terinfeksi), sel hati terinfeksi, kapsid DNA-VHB, dan virus bebas. Untuk berbagai nilai awal semua nilai solusi numerik sistem (14) konvergen ke $E_{0}$. Dalam simulasi numerik ini, pemilihan tiga nilai awal untuk mewakili kondisi manusia belum terinfeksi yaitu IC1, kondisi manusia terinfeksi ringan IC2, dan kondisi manusia terinfeksi lebih berat IC3. Sementara itu, pemilihan nilai parameter dilakukan berdasarkan syarat eksistensi titik $E_{1}$ yaitu $\Delta_{2}>0$ dimana pada Gambar 1 digunakan nilai parameter yang tidak memenuhi syarat eksistensi tersebut. Dalam simulasi ini, dipilih $\Delta_{2}<0$ atau

$$
a k \beta-(c+k)(\delta+p)(\beta+\delta)<0,
$$

yang menunjukkan bahwa tingkat infeksi lebih kecil dibandingkan tingkat kematian virus maupun sel terinfeksi. Jelas bahwa tingkat infeksi yang rendah mengakibatkan tidak terjadi penyebaran infeksi dalam jangka panjang sehingga populasi sel hati terinfeksi, kapsid DNAVHB, dan virus bebas bernilai nol atau mengalami kepunahan.

Untuk simulasi kedua, digunakan nilai parameter yang serupa kecuali untuk $c=5$ dan $p=0.35$. Pemilihan nilai tersebut mengakibatkan dua titik kesetimbangan eksis. Nilai eigen matriks Jacobi pada titik $E_{0}$ adalah (-0.01, 0.03, $0.95+0.49 \mathrm{i},-0.94-0.49 \mathrm{i})$, sedangkan nilai eigen matriks Jacobi pada titik $E_{1}$ adalah $\quad(-0.95+0.46 \mathrm{i}, \quad-0.95-0.46 \mathrm{i}, \quad-$ $0.21+0.01 \mathrm{i},-0.02-0.01 \mathrm{i})$. Oleh karena itu, titik $E_{0}$ tidak stabil sedangkan titik $E_{1}$ stabil asimtotik. Nilai dari titik kesetimbangan $E_{1}$ adalah

$$
E_{1}=(432.62,81.87,13074.43,22680.86) \text {. }
$$

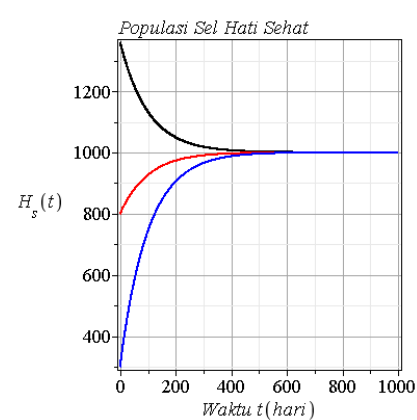

Populasi Sel Hati Terinfeks
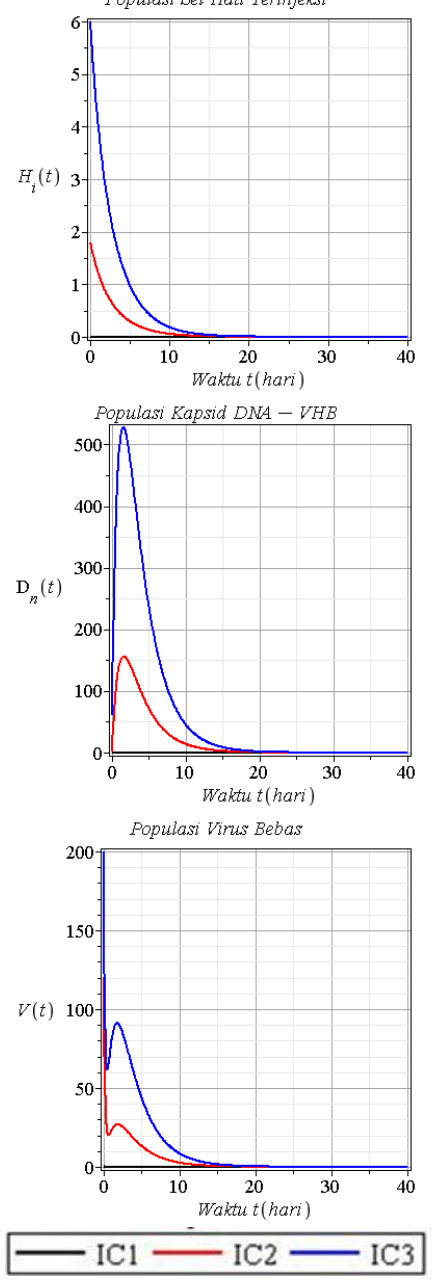
Gambar 1. Solusi numerik dengan titik $E_{0}$ stabil asimtotik yaitu populasi sel hati terinfeksi, kapsid DNA-VHB, dan virus bebas punah

Pada Gambar 2, diplot beberapa solusi menggunakan tiga nilai awal yang sama dengan simulasi pertama. Tampak bahwa semua nilai solusi numerik sistem (14) konvergen ke $E_{1}$.
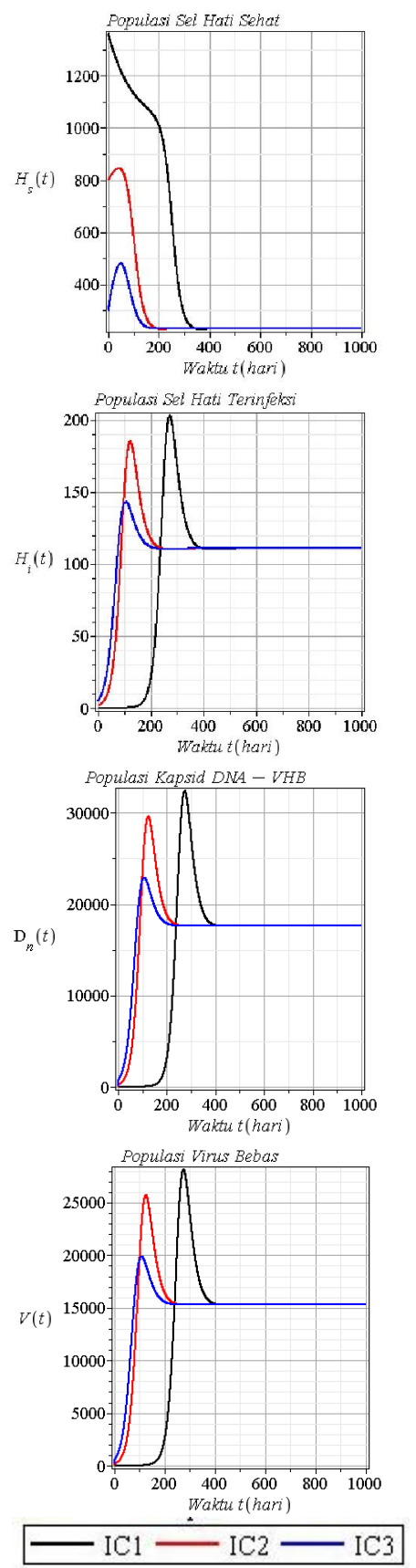

Gambar 2. Solusi numerik dengan titik $E_{1}$ stabil asimtotik yaitu populasi sel hati terinfeksi, kapsid DNA-VHB, dan virus bebas tetap eksis.

Perlu dicatat bahwa dalam simulasi kedua ini digunakan tingkat infeksi yang lebih besar dibandingkan tingkat kematian virus maupun sel terinfeksi, yaitu $\Delta_{2}>0$ atau

$$
a k \beta-(c+k)(\delta+p)(\beta+\delta)>0 .
$$

Hal ini mengakibatkan populasi virus akan tetap eksis dalam jangka panjang, serta mengakibatkan kepadatan populasi sel hati terinfeksi tidak akan bernilai nol. Situasi ini menggambarkan penyebaran infeksi berlangsung terus menerus atau dapat dikatakan sebagai kondisi infeksi persisten dalam jangka panjang.

\section{KESIMPULAN}

Pada penelitian ini, telah dipelajari model infeksi virus Hepatitis B dengan pengaruh penyembuhan dan absorpsi patogen secara numerik. Ditemukan bahwa model tersebut memiliki dua titik kesetimbangan $E_{0}$ yang menunjukkan kondisi bebas infeksi dan titik kesetimbangan $E_{1}$ yang menunjukkan kondisi terinfeksi dalam jangka panjang. Berdasarkan simulasi, masing-masing titik kesetimbangan bersifat stabil asimtotik dengan syarat tertentu. Dalam hal ini, syarat eksistensi titik kesetimbangan terinfeksi mempengaruhi kestabilan kedua titik kesetimbangan. Titik kesetimbangan $E_{0}$ stabil asimtotik jika $\Delta_{2}<0$. Sebaliknya, titik kesetimbangan $E_{1}$ stabil asimtotik jika $\Delta_{2}>0$. Hal ini mengindikasikan

$$
\frac{a k \beta}{(c+k)(\delta+p)(\beta+\delta)}
$$

sebagai bilangan reproduksi dasar model (14). Untuk itu, diperlukan analisis lebih lanjut untuk mendukung hasil tersebut, sekaligus untuk mengeksplorasi dinamika model secara analitik. 


\section{Ucapan Terima Kasih}

Penulis mengucapkan terima kasih kepada Direktorat Riset dan Pengabdian Masyarakat, Direktorat Jenderal Penguatan Riset dan Pengembangan, dan Kementerian Riset, Teknologi, dan Pendidikan Tinggi yang telah memberikan dukungan pada penelitian ini melalui skema Hibah Penelitian Dosen Pemula.

\section{DAFTAR PUSTAKA}

Bartholomeusz, A., Chang, J., Locarnini, S., Lewin, S., 2006. Replication of Hepatitis B Virus and Pathogenesis of Disease. Elsevier, pp. 111-123. https://doi.org/10.1016/b978-14160-3258-8.50012-7

Dubey, B., Dubey, P., Dubey, U.S., 2016. Modeling the intracellular pathogen-immune interaction with cure rate. Commun. Nonlinear Sci. Numer. Simul. 38, 72-90.

https://doi.org/10.1016/j.cnsns.20 16.02.007

Guidotti, L.G., 1999. Viral Clearance Without Destruction of Infected Cells During Acute HBV Infection. Science 284, 825-829. https://doi.org/10.1126/science.28 4.5415 .825

Hethcote, H.W., 1989. Three Basic Epidemiological Models, in: Levin, S.A., Hallam, T.G., Gross, L.J. (Eds.), Applied Mathematical Ecology. Springer Berlin Heidelberg, Berlin, Heidelberg, pp. 119-144. https://doi.org/10.1007/978-3642-61317-3_5

Manna, K., Chakrabarty, S.P., 2015. Chronic hepatitis B infection and HBV DNA-containing capsids: Modeling and analysis. Commun. Nonlinear Sci. Numer. Simul. 22, 383-395. https://doi.org/10.1016/j.cnsns.20 14.08.036

Pinkbook | Hepatitis B | Epidemiology of Vaccine Preventable Diseases | CDC [WWW Document], 2018. URL

https://www.cdc.gov/vaccines/pu bs/pinkbook/hepb.html (accessed 10.7.18).

Teo, E.-K., Lok, A.S., 2018. Epidemiology, transmission, and prevention of hepatitis B virus infection. UpToDate.

Wang, K., Fan, A., Torres, A., 2010. Global properties of an improved hepatitis B virus model. Nonlinear Anal. Real World Appl. 11, 3131-3138. https://doi.org/10.1016/j.nonrwa.2 009.11 .008

Yousfi, N., Hattaf, K., Tridane, A., 2011. Modeling the adaptive immune response in $\mathrm{HBV}$ infection. J. Math. Biol. 63, 933-957. https://doi.org/10.1007/s00285010-0397-x 